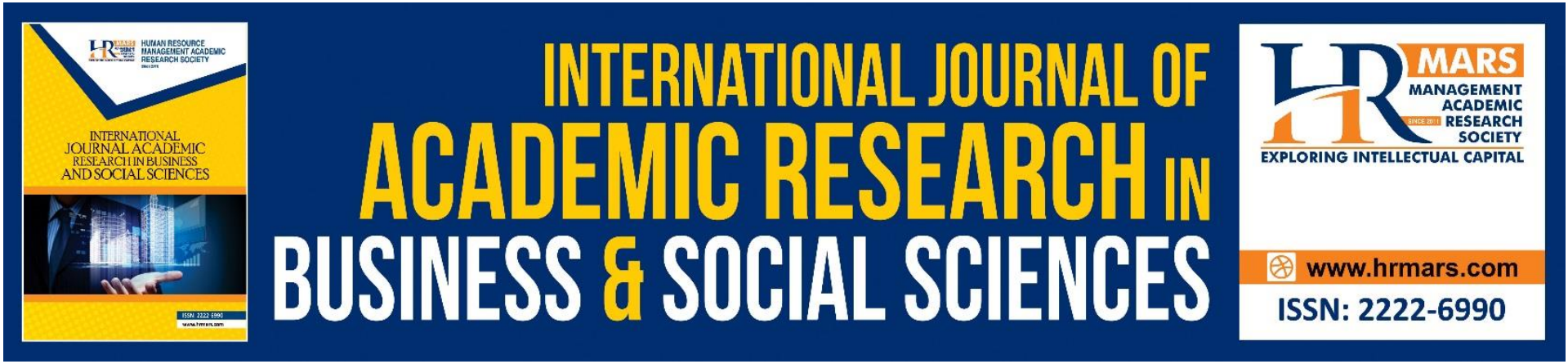

\title{
The Exploration of Empowerment: Participation of Urban Agriculture Communities with Presence of Social Capital
}

Nur Shuhamin Nazuri, Nobaya Ahmad, Mohd Roslan Rosnon, Mohd Harifadilah Rosidi, Siti Nur Shuhada Nazuri, Sara Shakilla Mohd Salim, Razif Sazali, Mohamad Firdaus Ahmad, Siti Shazwani Ahmad Suhaimi

To Link this Article: http://dx.doi.org/10.6007/IJARBSS/v12-i1/11909 DOI:10.6007/IJARBSS/v12-i1/11909

Received: 03 November 2021, Revised: 07 December 2021, Accepted: 27 December 2021

Published Online: 02 January 2022

In-Text Citation: (Nazuri et al., 2022)

To Cite this Article: Nazuri, N. S., Ahmad, N., Rosnon, M. R., Rosidi, M. H., Nazuri, S. N. S., Salim, S. S. M., Sazali, R., Ahmad, M. F., \& Suhaimi, S. S. A. (2022). The Exploration of Empowerment: Participation of Urban Agriculture Communities with Presence of Social Capital. International Journal of Academic Research in Business and Social Sciences, 12(1), 98-120.

Copyright: (c) 2022 The Author(s)

Published by Human Resource Management Academic Research Society (www.hrmars.com)

This article is published under the Creative Commons Attribution (CC BY 4.0) license. Anyone may reproduce, distribute, translate and create derivative works of this article (for both commercial and non0-commercial purposes), subject to full attribution to the original publication and authors. The full terms of this license may be seen at: http://creativecommons.org/licences/by/4.0/legalcode

Vol. 12, No. 1, 2022, Pg. $98-120$

Full Terms \& Conditions of access and use can be found at http://hrmars.com/index.php/pages/detail/publication-ethics 


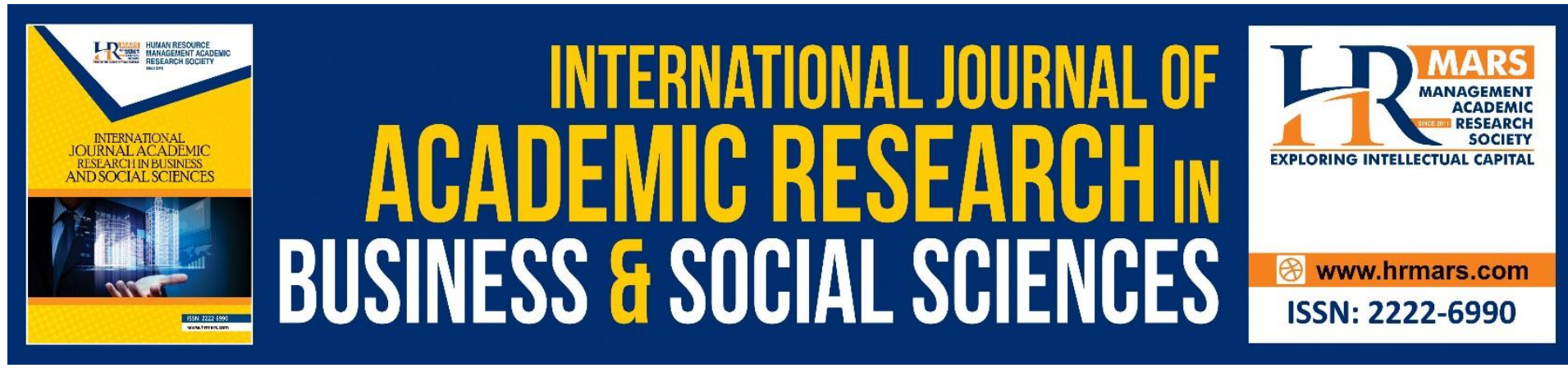

\title{
The Exploration of Empowerment: Participation of Urban Agriculture Communities with Presence of Social Capital
}

\author{
Nur Shuhamin Nazuria, Nobaya Ahmad ${ }^{a}$, Mohd Roslan \\ Rosnona ${ }^{a}$, Mohd Harifadilah Rosidi ${ }^{b}$, Siti Nur Shuhada Nazuric, \\ Sara Shakilla Mohd Salim ${ }^{\mathrm{d}}$, Razif Sazalie, Mohamad Firdaus \\ Ahmade, Siti Shazwani Ahmad Suhaimi ${ }^{a}$ \\ aFaculty of Human Ecology, Universiti Putra Malaysia, 43400 UPM Serdang, Selangor, \\ Malaysia, ${ }^{b}$ Faculty of Syariah and Law Universiti Sains Islam Malaysia, Bandar Baru Nilai, \\ Negeri Sembilan, Malaysia, 'Faculty of Business and Management, Universiti Teknologi \\ MARA, Shah Alam, Campus, Selangor, Malaysia, dFaculty of Human Sciences, Universiti \\ Pendidikan Sultan Idris, Tanjong Malim, Malaysia, Perak Darul Ridzuan, Malaysia, e Faculty of \\ Sports Science and Recreation, Universiti Teknologi MARA, Seremban, Campus, Negeri \\ Sembilan, Malaysia \\ Corresponding Author: nobaya@upm.edu.my
}

\begin{abstract}
In Malaysia, Urban Agriculture program's initiative has brought local communities together to grow their own food in designated areas and at the same time to empower the community (Bernama, 2020). According to Strzelecka et al (2017) participation is important in strengthening community empowerment. However, lack of participation among UA community resulted investment and initiative done by government to waste. This study aims to identify dimension of participation (planning, implementation and evaluation) level of Urban Agriculture (UA) program's respondents towards economic and social empowerment independently, where their effect is design to be moderated by social capital consisting of bonding, bridging and linking. This study recorded majority of the respondents were male, aged between 41-60 years old, married and has obtained secondary school/vocational. Majority of them have family members between 5 to 12 . Addition to that, relationship between participation, social capital towards empowerment among respondents were found to be insignificant. Hence, resulting social capital (bonding, bridging and linking) do not have moderator function on participation to empowerment.
\end{abstract}

Several recommendations for future studies were discussed. First, other new variable should be examined and future research will consider using qualitative methods to conduct in-depth discussions in order to identify any additional variables with the potential to influence empowerment of UA program's respondents. Secondly, future studies should consider in looking factors effecting of weak networking social capital, and the aspects of strengthening 
participation of UA program's respondents. Thirdly, other possible factors that possibly influence the empowerment of UA program's respondents should be investigate. It is anticipated that findings can be used as a basis for the future research related to UA program in Malaysia.

Keywords: Participation, Social Capital, Community Development, Empowerment, Food Security, Urban Agriculture

\section{Introduction}

Most of the time, agriculture has been associated with the imaginary of the rural environment. In fact, in order to feed the human populations, it was assumed that relying on rural crop production would be sufficient (Orsini, Kahane, Nono-Womdim \& Gianquinto, 2013). However, this turned out to be rather incorrect, as there was evidence that urban agriculture itself was able to cater to food demand for the urban population, given it was practiced in the proper way (Specht et al., 2014). Studies from both developed and developing countries claimed that UA activities have contributed to the availability of fresh and nutritious food, having direct access to varieties of food products, reduced food expenditure in the food bills as well as brought social benefits to the community (Turner, 2011). 
Table 1: Scenario of Urban Agriculture in the world

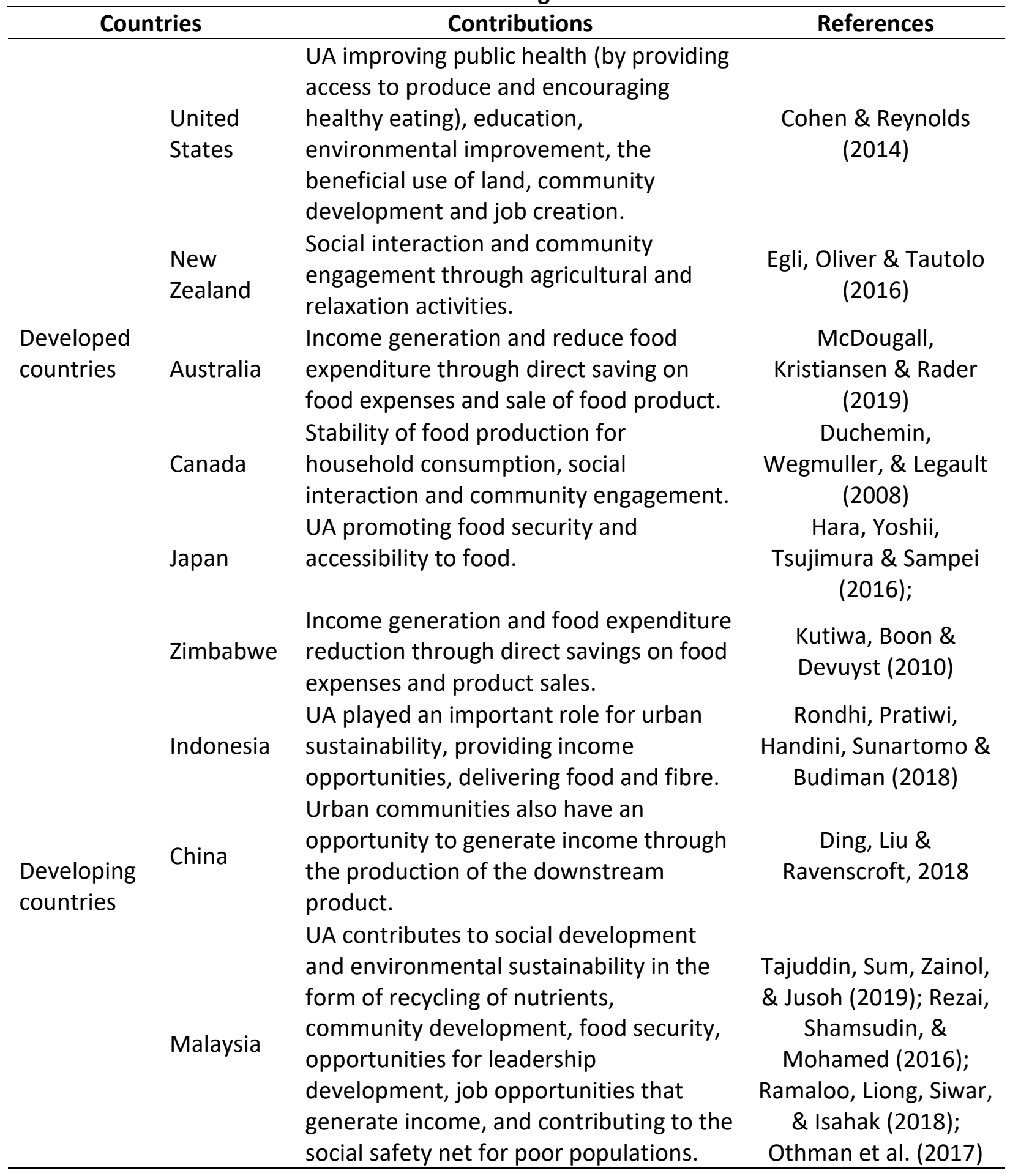

UA's implementation is most strongly related to issues of food insecurity and urban poverty (Kutiwa et al., 2010; Stewart et al., 2013). These difficulties disproportionately affect the urban poor, who are unable to afford their basic needs through food sources. This situation exists since urban communities rely on affordable, reliable, stable, accessible, and available food products (Rezai et al., 2016) from the formal food supply system or the market (Stewart et al., 2013). More precisely, the cost of food from a formal food supply system is higher than the cost of food from an informal food supply system because the whole cost of supplying, distributing, and obtaining the food product is higher (Kutiwa et al., 2010). In this 
context, the urban poor, tend to grow their own food within their house compound like in rural area. It is subjected to the interest of the urban communities to implement UA in order to gain side income through the production of agricultural output (Othman et al., 2017).

Undoubtably, UA is seen as the most sustainable practices that are needed by the urban communities as an alternative to maintaining food production for current and future generations. In conclusion, UA has been accepted globally including Malaysia as a strategy to address the adversity of the food crisis by ensuring adequate food security and nutrition. It also has increased household income and improved food access through the continuous production of agricultural products. Moreover, UA has a strong ability to bring neighborhoods together in order to develop and strengthen the community relationship. UA program also could create a place for social interaction, enhance the value of friendship, foster relationships and community cohesion (Othman et al., 2019; Yusoff et al., 2017; Tajuddin et al., 2019). Therefore, the conceptualization of UA as an informal urban food supply with the consideration of the theory of resilience is an explanation of the food crisis of food insecurity and urban poverty.

Having recognized the importance of UA, Malaysia was also considered as one of the developing countries that had practiced UA and it was not a new concept in Malaysia. The government also supported this initiative evident from the formation of the urban agriculture division, under the Department of Agriculture Malaysia (DOA) in 2010. The formation of UA division's goals was to promote agricultural activities in the city in order to reduce the urban community's cost of living, enhance urban community's extra income with surplus agricultural production, increase awareness and emphasize agricultural value as a direct contributor to reducing urban community living costs and guarantee food quality and safety in the country (DOA, 2018).

Moreover, this initiative comprehends with Sustainable Development Goal (SDG) who has been set up in 2015 by the United Nations General Assembly and is intended to be achieved by the year 2030. Multiple previous studies have revealed that active participation among UA programs' participants is vividly essential to building a strong and vibrant community, creating a sense of partnerships, enhancing community cohesion (Yusof et al., 2017), and strengthening the ties between communities (Nemore, 2015). The success of the UA program is dependent on continuous community participation in the implementation of the UA program (Yusof et al., 2017). UA's value is not simply its contribution to basic food security, but also the sense of pride that comes from using one's land productively (Hovorka, 2006). In addition, there are various social benefits associated with being involved in UA that enhance the livelihood strategies of poor households (Davies et al., 2021). In essence, social capital refers to the ability "to secure benefits by virtue of membership in social networks" (CofréBravo, Klerkx, \& Engler, 2019) and is an important element of sustainable livelihoods, as it can unlock economic, human, and other capitals (Carolan, 2016). Cultivators develop social capital when they share land, work together and donate portions of their harvest to neighbors. This social capital increases their access to food and other resources (Poulsen et al., 2015). At a macro-scale, cultivators who group together are more able to make their needs known to the local government (Asomani-Boateng, 2002; Mackay, 2018). For low-income households, livelihood resilience relates to the portfolio of capitals to which the household has access (Chambers \& Conway, 1992). "Capital" in the sustainable livelihood's framework refers not 
only to the strict economic definition of "the product of investment which yields a flow of benefits over time" (Department for International Development, 1999) but indicates livelihood "building blocks" that collectively contribute towards resilience (Farrington et al., 1999). Constructing a portfolio of capitals that includes access to natural, physical, human and social capital, in addition to financial capital, is vital for low-income households to build a resilient livelihood (Farrington et al., 1999). Thus, low-income households typically draw on multiple strategies and incomes, such as casual labor, state grants, and urban agriculture (Rakodi, 2002), as well as neighbors, friends, and family, to survive (Getz, 2008). However, attracting urban communities to participate in the program has become the key challenge for local authorities (Ramalingam et al., 2018). As mentioned by Strzelecka, Boley and Woosnam (2017) participation is important in strengthening community empowerment and it has a great potential to also improve socio-economic conditions of the community (Martin \& Traissac, 2012) which leads to sustainability of the development program (Lyndon et al., 2015).

The role of the community is very crucial in the implementation of UA programs (Yusoff et al., 2017). Hence, the focus of the study is to explore whether participation and social capital among UA community programs influenced the empowerment of the community. The justification for the need to investigate if participation and social capital can affect social empowerment is due to the nature of the UA programs which is voluntary in nature and to ensure sustainability in the program, therefore, there is a need to look into social empowerment of the participants who are in the program. The assumption is that if participants are empowered and reaping the benefits of their participation, there is a high chance of the programs attracting more participation from the residents. However, there is also a need to look into the social capital of the residents considering that the study will be investigating the interaction patterns of urban residents where the level of social capital is known to be low_Social capital was used in many community studies related to community programs such as indigenous group (Zal et al., 2013); squatter settlement (Babaei et al., 2012); rural community (Abdul-Hakim et al., 2010; Sheikh et al., 2015) but not in UA community. Previous studies were done by Babaei et al (2012); Zal et al (2013) also have looked into social capital in other communities and claimed that social capital is an important determinant of community empowerment.

In the context of this study, if the problem of empowerment among the community cannot be ascertained, certainly the UA program cannot be sustained. Therefore, how do we empower the community to ensure the sustainability of the program? Furthermore, all the investments and initiatives done by the government will go to waste if the communities who participated in the program is still not empowered, thus may affect the sustainability of the program in the long run. While many studies have looked at the direct relationship between participation, social capital, and empowerment respectively, can social capital moderate the relationship between participation and empowerment? The assumption is that, if low level of participation contributes to low level of empowerment, social capital can moderate the relationship between participation and empowerment. Therefore, the objectives of this study are:

- To describe the socio-demographic characteristics of the UA program's respondents and background of UA activities. 
- To investigate the relationship between participation and empowerment of the UA program's respondents

- To investigate the relationship between social capital and empowerment of the UA program's respondents

- To determine the moderating effect of social capital in the relationship between participation and empowerment of the UA program's respondents.

\section{Literature Review}

\section{Participation towards Empowerment}

Community participation is described in which individuals are involved in mobilizing and organizing the program to achieve community objectives and gradually steps forward towards the quality of life in the community environment (Samah \& Aref, 2009). Participation enhanced a 'sense of ownership' among community members (Mark \& Davis, 2012) which lead to positive outcomes within the community (Brown, 2005). Participation may reduce social isolation among the community, enhance their self-efficacy (Abbott, 2010) and bring sustainability towards the program (Samah et al., 2013). In fact, community participation is widely believed to be beneficial to community program development (Haldane et al., 2019). The word participation had become a twin strategy to promote sustainable development and people-centered development (Craig \& Mayo, 1995). Participation was a central concept and foundation principle which was widely and commonly used within community development (Nikkhah \& Ma'rof, 2009). Previous literature review showed finding on the relationships between participation and community development. Participation and community development are viewed as a process of transforming people's lives in all angles socially and economically aspect and reforming the community development (Oakley, 1989). Community participation also could be seen as a medium for empowerment to take place. Zimmerman and Rappapot (1988) in their study found a close connection between measures of community participation and empowerment. He concluded that empowerment connected perceived competence, motivation to take action, and actual participation for the public benefits. In his study in 1990, he supported that although participation directly reduces alienation, it also directly affected empowerment.

Participation was an effective strategy to increase the social level of the community. Rahman and Naoraze (2007) conducted research to study women's empowerment in rural areas through their participation in agricultural activities in Bangladesh. Findings from the study indicated that there was a significant relationship between their participation and empowerment. It showed that the participation of women in agricultural activities was significantly and positively correlated with empowerment. During participation, people in a group engaged in identifying problems, doing a decision making, and implementing a program, whereby they could learn together, developed their confidence, skills and subsequently contributed to their development (Samah \& Ndaeji, 2012). Similarly, Ani et al. (2018) clarified that people who had been participated have an ability to confront and overcome limitations while striving to solve problems either individually or collectively.

On the other hand, participation was believed to play a vital role in determining successful economic activity. Research conducted by Kumar (2006) proved that participation in the community development project played a transformative role in alleviating poverty and inspired women to achieve gender equality. Besides, participation also inculcated the values of teamwork, leadership skill, and building their capacities to generate income. He 
emphasized that participation in self-help development projects increased their socioeconomic status, improved their standard of living and position in society.

A study was done by Danjuma et al (2011) also found that participants who involved in selfhelp group programs have strengthened their socio-economic status by learning how to generate income, train for different business ventures, and develop for economic culture. She concluded that participation had obviously created a tremendous impact on participants' lifestyles especially in rural areas and empowered them at various levels as well as family members and the community as a whole.

However, the extent to which Malaysians are aware of the positive impact of UA remains uncertain. On the other hand, the UA program's participants also found that gardening is difficult, required intensive care, is costly, and required a substantial amount of time. They prefer to purchase vegetables and fruits in the supermarket, without realizing the fact that this contributes to the increase in the cost of living in the urban (Othman et al., 2020). It can be concluded that the success rate of this project is considered low and sustaining participation in the UA program need to be addressed by the local authorities (Ramaloo et al., 2018). Malaysia has a long way to go before people fully embrace UA as a necessity and not just a trend (Othman et al., 2017). Gaining the acceptance and participation community for a specific program is generally recognized as necessary for its success and survival (Poulsen et al., 2014).

This section reviewed how participation by programs' participants becomes a channel for their empowerment. To this end, a lack of research work specifically on the participation of UA community participants and their empowerment has been reported in Klang Valley. Thus, this study preserved that participation and empowerment were clearly associated. The study mentioned that the level of participation of participants (planning, implementation, evaluation) in programs will influence their level of empowerment, socially and economically as meaningful empowerment and participation required significant changes in power relationships.

\section{Social Capital towards Empowerment}

Several findings had proved that social capital and empowerment were linked with one another (Babaei et al., 2012; Eklinder-Frick, et al., 2012; Shimpo et al., 2019; Yokoyama and Ishida, 2006). Studies done by Narayan and Pritchett (2000) looked at the importance of social capital among farmers in the rural area. A strong social capital among farmers would influence their facilitation in community services which will lead to higher advances in farming and development practices. Yokoyama and Ishida (2006) also pointed out that the concept of social capital was beneficial in community development programs to improve the well-being of rural dwellers. Besides, it could make value for communities by strengthening the network structure, which upholds inside a mutual trust that offers for a greater outcome (EklinderFrick et al., 2012).

Another study had been done by Shimpo et al (2019) clarified that social capital among community gardens helped the community to share their experience and improve their level of consciousness, awareness, decision-making abilities, and wellbeing. It also facilitated resources from the outside of the community and became a value for the community to achieve the benefits (Eklinder-Frick et al., 2012). On the other hand, Babaei et al (2012) and Rilwanu (2014) also found out that social capital was important in enhancing farmers' economic well-being. Social capital in its best form contributed to economic development by providing information, justifying opportunistic behavior, and facilitating collective decision- 
making and empowerment (Babaei et al., 2012). Rilwanu (2014) indicated that social capital influenced farmers' economic empowerment in agriculture production cooperatives in Isfahan. The interaction of social capital enabled participants to share their knowledge with each other to engage in peer mentoring in financial assets and marketing strategies. As a consequence, it helped to develop trust among participants and their stakeholders which in turn, strengthened the community. In fact, social capital and empowerment were multilevel concepts that benefit the community and reduced the poverty.

The consequences of social capital during participation in gaining empowerment was something unconstrained among scholars of community development. But, to the best of the researcher's knowledge, a lack of study was available on the issue where social capital among program's participants was used as a moderating phenomenon in the UA program with three dimensions namely bonding, bridging, and linking to achieve empowerment among program's participants, which confirms a significant level of gap-spotting related to particular studies and attracted the researcher to conduct a study on the issue.

\section{Methods}

The data for this paper was gathered using a multistage random sampling method. A total of 212 respondents from UA program's participants in Klang Valley area were selected as the respondents. This study was employed a structured self-administered questionnaire through a survey method since it was an effective way for a researcher to measure the variables and interests. The questionnaire was adapted based on previous researches and modified according to this study. To achieve the objective, the instrument will be translated into bilingual, English, and Malay. The questionnaire consists of four sections (Section A, B, C and D) using the 5-points Likert scale as the response rate of the respondent. Section $A$ is the socio-demographic respondents' section consisting of 7 items. Section B is participation variable consisting of 3 dimensions (planning, implementation and evaluation) that have been adopted from (Rilwanu, 2014). For Section C is social capital consists of three dimensions which are bonding, bridging and linking, adapted from (Ibrahim, 2016). Meanwhile for Section $D$ consists of two dimensions which are social and economics that have been adapted from (Ndaeji, 2014; Rezai, 2014). Descriptive statistics such as frequency, percentage were used to fulfil the determined objective. PLS SEM analysis was used to test the relationship between participation, social capital, and empowerment of the UA program's respondents.

\section{Results \& Discussion \\ Demographic Respondents}

Table 2 below explains the socio-demographic characteristics and background of UA activities of respondents involving age groups, gender, marital status, level of education, number of households, working sectors, type of participation, and years of involvement in UA program. The majority of respondents were in the age group of $41-60$ years old (64.6\%) while the minority of them were among age $21-40$ years old (10.8\%). The respondents' age is ranged from 21 to 74 years old. The age's mean score is 53.76, showing that most of them are in the old age range. A large number of the respondents were male $(62.7 \%)$ and a few $(37.3 \%)$ were female. In terms of marital status, it was clarified that $94.3 \%$ were of a married couple that participate in the program, followed by $4.2 \%$ were single and $1.4 \%$ were a widower. As for educational level, the result noticed that $62.3 \%$ of respondents were secondary school/vocational leavers. Apart from this, $32.5 \%$ of respondents hold diploma/degree from colleges and universities, while the rest of percentage of respondents (5.2\%) were from 
primary schools. Based on the result, two-third of the respondents $(61.8 \%)$ were found to have $5-12$ households whereas $38.2 \%$ were between $0-4$ households.

Table 2: Socio-demographic characteristics and background of UA activities ( $n=212$ )

\begin{tabular}{lcc}
\hline Variables & Frequency & Percent \\
\hline Age Groups & 23 & \\
$21-40$ & 137 & $10.8 \%$ \\
$41-60$ & 52 & $64.6 \%$ \\
61 and above & & $24.5 \%$ \\
Average: 53.76 & & \\
Gender & 133 & \\
Male & 79 & $62.7 \%$ \\
Female & & $37.3 \%$ \\
Marital Status & 9 & \\
Single & 200 & $4.2 \%$ \\
Married & 3 & $94.3 \%$ \\
Widow/widower & & $1.4 \%$ \\
Level of Education & 11 & \\
Primary school & 132 & $5.2 \%$ \\
Secondary school/Vocational & 69 & $62.3 \%$ \\
College/ University & & $32.5 \%$ \\
Number of households & 81 & \\
0-4 & 131 & $38.2 \%$ \\
5-12 &
\end{tabular}

\section{Measurement Model}

\section{Model Evaluation}

In this study, the discussion of PLS-SEM comprises of two models namely hierarchical component model (HCM) and structural model. The objective of HCM is to measure internal consistency (CR), convergent validity (AVE and loadings), collinearity (VIF), significance and coefficients of determination $\left(R^{2}\right)$, $t$ values, $f^{2}$, and interaction plot. In regard to the structural model, the purpose of the analysis is to determine the model's predictive capabilities and the association between the constructs. After completing the hierarchical component model, the structural model will be followed.

\section{Hierarchical Component Model (HCM) Two-stage Approach i) Stage 1}

In stage 1, five criteria are needed to be evaluated which are internal consistency (CR), convergent validity (AVE and loadings), collinearity (VIF), significance, and coefficients of determination $\left(R^{2}\right)$. The detailed result of each criterion is discussed in the following subsections.

\section{a) Internal Consistency Reliability}

Internal consistency is a form of reliability used to determine the consistency of the items in the construct. It determines whether the items measuring a construct are similar in their scores. Composite reliability is a more suitable measure as this type of reliability takes into 
account the different outer loadings of indicator variables. The values of composite reliability $(\mathrm{CR})$ varies between 0 to 1 , with higher values indicating a higher level of reliability. Based on Table 3, Composite Reliability (CR) is between 0.941- 0.950 which indicates the acceptable internal reliability of all variables (Straub, Boudreau \& Gefen, 2004). Meanwhile, for composite reliability (CR) the highest value is Bridging (BRI), Planning (PLAN) and Economic Empowerment (ECEM) at 0.950, Implementation (IMP) at 0.949, Evaluation (EV) at 0.947, Social Empowerment (SOCEM) at 0.944 and Bonding (BON) at 0.943.

\section{b) Convergent Validity}

Convergent validity describes as internal consistency on the set of items to be measured. It represents the strength of a relationship of each item that is predicted to represent a single latent construct. Therefore, the characteristics of items must strongly relate to each other and represent only one factor. According to Hair et al., (2010), factor loading greater than 0.5 indicated the latent variable has high convergent validity. In this study, factor loadings for items PLAN 2, PLAN 4, IMP 4, EV 2, BON 3, BON 5, BRID 2, BRID 4, LINK 5 are below 0.5 and has been deleted through the scale refinement process as all the items excluding the recommended value suggested. For the AVE constructs, the value is 0.5 above as recommended by Hair et al. (2014) with the highest achieved is Evaluation at 0.927, followed by Planning at 0.902 , Bridging at 0.866 , Bonding at 0.847 , Linking at 0.800 , Implementation at 0.790, Economic Empowerment at 0.760 and the lowest is Social Empowerment at 0.654. 
INTERNATIONAL JOURNAL OF ACADEMIC RESEARCH IN BUSINESS AND SOCIAL SCIENCES Vol. 12, No. 1, 2022, E-ISSN: 2222-6990 @ 2022 HRMARS

Table 3: The results of reflective measurement model

\begin{tabular}{|c|c|c|c|c|}
\hline Constructs & Items & Loadings & $\begin{array}{c}\text { Composite } \\
\text { Reliability } \\
\text { (CR) }\end{array}$ & AVE \\
\hline \multirow[t]{3}{*}{ Planning } & PLAN1 & 0.956 & 0.950 & 0.902 \\
\hline & PLAN3 & 0.953 & & \\
\hline & PLAN5 & 0.940 & & \\
\hline \multirow[t]{5}{*}{ Implementation } & IMP1 & 0.864 & 0.949 & 0.790 \\
\hline & IMP2 & 0.911 & & \\
\hline & IMP3 & 0.909 & & \\
\hline & IMP5 & 0.876 & & \\
\hline & IMP6 & 0.883 & & \\
\hline \multirow[t]{3}{*}{ Evaluation } & EV1 & 0.958 & 0.947 & 0.927 \\
\hline & EV3 & 0.972 & & \\
\hline & EV4 & 0.959 & & \\
\hline \multirow[t]{3}{*}{ Bonding } & BON1 & 0.941 & 0.943 & 0.847 \\
\hline & BON2 & 0.935 & & \\
\hline & BON4 & 0.884 & & \\
\hline \multirow[t]{3}{*}{ Bridging } & BRI1 & 0.939 & 0.950 & 0.866 \\
\hline & $\mathrm{BRI3}$ & 0.952 & & \\
\hline & BRI5 & 0.900 & & \\
\hline \multirow[t]{4}{*}{ Linking } & LINK1 & 0.832 & 0.941 & 0.800 \\
\hline & LINK2 & 0.895 & & \\
\hline & LINK3 & 0.923 & & \\
\hline & LINK4 & 0.924 & & \\
\hline Economic & ECEM1 & 0.863 & 0.950 & 0.760 \\
\hline \multirow[t]{5}{*}{ Empowerment } & ECEM2 & 0.876 & & \\
\hline & ECEM3 & 0.874 & & \\
\hline & ECEM4 & 0.880 & & \\
\hline & ECEM5 & 0.868 & & \\
\hline & ECEM6 & 0.871 & & \\
\hline \multirow[t]{9}{*}{ Social Empowerment } & SOCEM1 & 0.731 & 0.944 & 0.654 \\
\hline & SOCEM 2 & 0.888 & & \\
\hline & SOCEM3 & 0.860 & & \\
\hline & SOCEM4 & 0.771 & & \\
\hline & SOCEM5 & 0.848 & & \\
\hline & SOCEM6 & 0.867 & & \\
\hline & SOCEM7 & 0.793 & & \\
\hline & SOCEM8 & 0.841 & & \\
\hline & SOCEM9 & 0.648 & & \\
\hline
\end{tabular}

\section{c) Collinearity Issue (VIF)}

Table 4 shows the VIF value of PAR, SC, and EMP in each respective indicator is below 5.335, which indicated that the collinearity issue is absent for these constructs. 
Table 4: The Variance Inflation Factor (VIF) of all constructs

\begin{tabular}{lc}
\hline Construct/Indicator & VIF \\
\hline Participation & \\
Planning & 4.700 \\
Implementation & 3.202 \\
Evaluation & 4.526 \\
Social capital & \\
Bonding & 2.846 \\
Bridging & 5.326 \\
Linking & 3.990 \\
Empowerment & \\
Economic Empowerment & 3.165 \\
Social Empowerment & 5.335 \\
\hline
\end{tabular}

\section{d) Assess the Significance and Relevance of the Constructs}

Results from Table 5 indicated that the indicators (items) of SC, PAR, and EMP are significant at $p<0.05$. Thus, all the indicators namely Planning, Implementation, Evaluation, Bonding, Bridging, Linking, Social empowerment, and Economic empowerment are significant $(p<0.05)$ in explaining SC, PAR, and EMP with t value are 29.866, 46.656, 25.469, 29.231, 15.677, $20.102,83.319$ and 42.140 respectively.

Table 5: The results of the Significance and $t$ value of indicators

\begin{tabular}{lll}
\hline Indicators & t-value & p-value \\
\hline Planning-> PAR & 29.866 & 0.000 \\
Implementation-> PAR & 46.656 & 0.000 \\
Evaluation -> PAR & 25.469 & 0.000 \\
Bonding -> SC & 29.231 & 0.000 \\
Bridging -> SC & 15.677 & 0.000 \\
Linking -> SC & 20.102 & 0.000 \\
Social Empowerment -> EMP & 83.319 & 0.000 \\
Economic Empowerment-> EMP & 42.140 & 0.000 \\
\hline
\end{tabular}

\section{e) Coefficients of Determination, $R^{2}$}

The researcher then proceeds to the next step which is $R^{2}$. Referring to Hair et al. (2011), the important evaluation criteria for the goodness of the model is $R^{2}$ measures. $R^{2}$ represents the amount of variance explained by all the exogenous constructs. The coefficient denotes the exogenous latent variables' combined effects on the endogenous latent variable. The coefficient of determination also indicates the amount of variance in the endogenous constructs explained by all the exogenous constructs linked to it. The $R^{2}$ value ranges from 0 to 1 with higher levels indicating higher levels of predictive accuracy. Table 6 shows the value of $R^{2}$ of the endogenous construct (empowerment) explained by all the exogenous constructs (participation and empowerment). The results of current research show that the $R^{2}$ value for participation is 0.997 suggesting that $99.7 \%$ of the variance in participation can be explained by empowerment. Meanwhile, the $R^{2}$ of social capital is 0.994 which indicates that $99.4 \%$ of the variance in social capital can be explained by empowerment. 
Table 6: Coefficient of Determination, $R^{2}$

\begin{tabular}{cc}
\hline Variables & $\boldsymbol{R}^{\mathbf{2}}$ \\
\hline Participation & 0.997 \\
Social capital & 0.993
\end{tabular}

\section{ii) Stage 2}

The analysis in stage 1 is confirmed reliable, valid, and has no collinearity issues based on the analysis performed. The study proceeds with stage 2 that begins with three criteria which are effect size $\left(f^{2}\right)$, significance and relevance of the constructs, and the interaction term. The detailed result of each criterion is discussed in the following subsections.

\section{a) Effect size $\left(f^{2}\right)$}

Table 7 shows the effects sizes of the respective endogenous variables. The results revealed that participation and social capital on empowerment have no effect with $f^{2}$ is recorded at 0.004 and 0.001 respectively.

Table 7: Effect size, $f^{2}$

\begin{tabular}{lcc}
\hline Path & $\boldsymbol{f}^{2}$ & Effect size \\
\hline Participation -> Empowerment & 0.004 & No effect \\
Social Capital -> Empowerment & 0.001 & No effect \\
\hline
\end{tabular}

\section{Structural Model}

After evaluating the hierarchical component model, the researcher proceeds with structural model analysis. The purpose of the structural model is to determine the model's predictive capabilities and the association between the constructs. The present research proceeds with a structural model evaluation that begins with collinearity issues (VIF), significance and relevance of structural model relationships, $R^{2}$ level, effects size $\left(f^{2}\right)$, and predictive relevance $Q^{2}$. The subsequent subsections discuss and present each of the assessments together with the results obtained.

\section{Collinearity Assessment (VIF)}

Table 8 shows the VIF value of all the constructs in the structural model and it is observed that there is no collinearity issue present in the model as all the VIF values are ranging from 1.947 to 3.445 , which is below the threshold of 5.0,

Table 8: The Variance Inflation Factor (VIF) of all constructs in Structural Model

\begin{tabular}{lc}
\hline Construct/Indicator & VIF \\
\hline Participation & 1.947 \\
Social Capital & 3.445 \\
\hline
\end{tabular}

Source: Developed for the present research

\section{Hypotheses Testing}

The research tested a total of three hypotheses. Hypothesis 1 and 2 tested the direct relationship between participation, social capital, and empowerment whereas hypothesis 3 tested the moderating effect of social capital on the relationship between participation and empowerment (Table 9). To test the hypotheses, PLS-SEM along with moderation analysis was used and information of the analyses are discussed in the next part of this thesis. The 
result shows that $\mathrm{p}=0.379$ and $\mathrm{t}$ value is 0.881 which confirmed that $\mathrm{H}_{1}$ was not supported. It shows that participants have an insignificant relationship with empowerment. The path analysis result shows that $\mathrm{p}=0.648$ and $t$ value is 0.456 which confirmed that $\mathrm{H}_{2}$ was not supported. It shows that social capital has an insignificant relationship with empowerment. In order to analyze the moderating effects, the direct relations of the exogenous and the moderator variable as well as the interaction term with the endogenous variable are examined (Henseler \& Fassott, 2010). Bootstrapping procedure is employed to test the significance of the path coefficient. If the path coefficient is significant, the next step is to measure the strength of the identified moderating effect. In this research, social capital (SC) is the continuous moderator which is hypothesized to moderate the relationship between participation and empowerment. In this study, it is hypothesized that social capital does not moderate empowerment of participation.

Table 9: The significance of the path coefficients

\begin{tabular}{lcc}
\hline \multicolumn{1}{c}{ Construct relationship } & t-value & p-value \\
\hline Participation -> Empowerment & 0.881 & 0.379 \\
Social capital -> Empowerment & 0.456 & 0.648 \\
Moderating Effect of SC ->EMP & 0.878 & 0.380 \\
\hline
\end{tabular}

Predictive Relevance, $Q^{2}$

$Q^{2}$ values are calculated as the last part of the structural model evaluation (Stone, 1974). Table 10 reveals that the $Q^{2}$ values of Participation and Social Capital based on the blindfolding procedure are larger than zero which signifies that the result has a good predictive relevance in the structural model (Hair et al., 2014).

Table 10: Predictive Relevance, $Q^{2}$

\begin{tabular}{lc}
\hline Constructs & $\boldsymbol{Q}^{\mathbf{2}}$ \\
\hline Participation & 0.990 \\
Social Capital & 0.987 \\
\hline
\end{tabular}

\section{Discussion}

Based on the background of the study, it can be concluded that the majority of the respondents are between 41-60 years old age range (64.6\%) with a mean age of $M=53.76$. The result reflected that elders are more likely to participate in the program since most of them are retired and have a lot of time to engage with the community. Their expertise is often used and became a role model for youth to be involved in project activities. In accordance to Sheikh et al (2015); Rilwanu (2014), Viscogliosi et al (2020), elders tend to have more experience and knowledge, which enables them larger opportunities to exchange ideas and have close relationships with the community. The elderly is probably more mature in decision making, aware of the current issue, and matured to think on how to develop a strong society with current economic and social development (Sheikh et al., 2015). Therefore, it is a good indicator for government to play a part in attracting the elderly to participate in the UA program in the future to ensure the sustainability of the program.

In terms of gender, the result portrayed that the study population was dominated by the male which comprises about $62.7 \%$ of respondents. This category indicates that these respondents 
were from the productive workforce of the Malaysian population and willing to spend their time participating in community activity. Past studies have discovered that men generally report higher empowerment in formal organizations in all types of society compared to women (Othman et al., 2019). Besides, this is prior to research done by Nazuri et al (2021) that has shown that men are more interested and available to join UA programs. Males received more opportunities to participate in community programs. They are more active, more aware of any issue, and play the role of the breadwinner (Othman et al., 2019). With superior access to resources and a stronger voice in home and society, males often freely engage in political and social activities that allow them to acquire the vital resources required to enhance their institutional capacity. Babaei et al (2012) also stressed that men actively engaged in social activities, whereas women spend more time on domestic work and childcare and are less engaged in interactions with other people outside their home. This study also revealed a large number of married couples (94.3\%) participate in this program since the neighborhood usually consists of family and married people. Another reason is that married people have other social and economic responsibilities. This responsibility triggered them to participate more in these activities. This finding was supported by Ramalingam, Sharifuddin, Mohamed and Ali (2019); Shamsudin et al (2014) who discovered the majority of respondents who were involved in the UA program in Malaysia were married. At this level, they might have learned more about the society, reality of life and also had marriage experiences which are the good background that will enable them to actively participate and demonstrate their volunteerism in the group activities. Findings from this study also noted that almost twothirds of the respondents (62.3\%) attended secondary school/vocational school which showed that the majority of them have a moderate level of education. Based on the result, two-third of the respondents (61.8\%) were found to have between 5-12 numbers of household and $38.2 \%$ have between $0-4$ numbers of households.

The result indicated a non-significant relationship between participation towards empowerment where the $p$-value is 0.379 and the $t$ value is 0.881 . It concluded that the significance of empowerment was not affected by the participation of the UA program's respondents. Such a result is not in line with a study done by Rilwanu (2014), who indicated that community involvement and participation in developmental activities lead to empowerment and gaining control over their own lives. Furthermore, several researchers highlighted that a critical factor to ensure community sustainable development is the active community participation - the more active community participation in the program, the more empowered the community and consequently will lead to sustainable community development (Rilwanu, 2014).

In Abdul Hamid (2008), the finding also shows that in order to achieve empowerment; it requires active participation from the community members. Moreover, Lim (2010) in her finding exhibit the higher the level of participation likely in the planning, implementation, and evaluation process, the higher the level of empowerment. This indicates the moderate level of participation among UA communities in Klang Valley was not robust enough in influencing the communities to be empowered. It denotes that high participation is required among Klang Valley UA communities to ensure the repercussion of UA is adequate to encourage empowerment among the urban societies. However, regardless of the direction of participation and empowerment was found to be insignificant, the direction of this effect was 
shown to be positive. This indicates that even though participation does not affect empowerment, it does not weaken or disrupt the relationship.

Social capital consists of three dimensions, which are bonding, bridging, and linking. In this present research, social capital recorded an insignificant relationship with empowerment at $t$ value $=0.456$ and $p$-value $=0.648$. The relationship between social capital was found to be insignificant to empowerment. The outcome of this study provides evidence that the UA program in Malaysia does not require social capital to drive the community to engage in the program, which contradicts the hypothesis made earlier in this study. This finding indicates a different reality with studies done by Abdul-Hakim et al (2010); Babaei (2012), who found that people with a high level of social capital assisted in the resolution of problems and the facilitation of more cooperative actions among group respondents. According to them, community-to-community engagement allowed them to share their expertise and participate in peer mentoring programs. The direction of social capital and empowerment was found to be insignificant however, the direction of this effect was shown to be positive. This evidence suggests that even though social capital does not affect empowerment, it does not weaken or disrupt the relationship.

The results of moderating effects showed that the social capital dimension does not moderate the relationship between participation and empowerment of the UA program's respondents ( $\mathrm{t}$ value $=0.878, \mathrm{p}$-value $=0.380$ ). The results revealed that social capital dimensions among them are at a moderate level and unable to become a moderator and develop the collective effect of participation towards empowerment. In other words, in UA practices among urban dwellers context, the impact of social capital on participation is insignificantly faint to constitute an empowered community. In line with findings done by Bridger and Alter (2006); Smith (2005), who emphasized that many inner cities communities always have a serious shortage of social capital. Besides, the urban community also has a lack of communication, trust, and ineffective social control (Wilson, 1996). A community with a low level of trust will decrease community willing to take action to improve the situation in their neighborhood (Shirlow \& Murgah, 2004).

On the other hand, Park et al (2015) also mentioned that social capital is considered as the "missing link" in economic development. As interact with one another (i.e., UA programs); the socialization and reciprocity established through social networks produce interpersonal trust and enable citizens to cooperate in pursuing shared goals. As it is built on interpersonal trust and informal socializing, social capital establishes an essential condition for enabling participation (Kim, 2007). Moreover, social capital can provide an appropriate foundation for human resources to benefit from, so that human resources can fulfill their commitments by more participation, reciprocal trust, and increasing their professional knowledge (Mirsepasi, 2004). However, in the context of agriculture, a low level of social capital leads to illmanagement (Gong et al., 2010). With a moderate level of social capital among the Klang Valley UA communities, it is a comprehensible rationale for its non-significant effect on participation towards empowerment. It is due to the recent developments in agriculture that have witnessed the collapse of co-operative practices, a decrease in time availability, and the ongoing decline in the number of upland farmers (Burton \& Lim, 2005; Heenan, 2010). This in turn leads to a loss in the overall levels of social capital in agricultural sectors (Burton \& Lim, 2005). In conclusion, lack of social capital may lead to limited uptake of sustainable practices; 
hence participation. Where this is the case, strategies to address this would benefit from incorporating measures focused on building bonding, bridging, and linking social capital (Rust et al., 2020). However, a study focusing on the impacts of social capital on UA respondents in moderating participatory remains inconclusive.

\section{Conclusion}

While wrapping up the results of the study, the researcher arrived at the conclusion of the background of UA community respondents in the Klang Valley area majority were male elders and had married. Besides, most of them are secondary school/vocational school leavers and had a number of households in between 5-12 members. Our first dependent variable specifically social empowerment measured the ability of UA program's respondents to gain control over their lives by developing new skills, generating new knowledge, and enhancing capability throughout the UA program. Other than social empowerment, this study also further scrutinized the economic empowerment of the program's respondents. Economic empowerment is measured as respondents' ability to reduce their expenditures on fresh food intake such as vegetables generate their income through selling surplus production from UA activities. There are three dimensions of participation namely planning, implementation, and evaluation level expected to have an impact on social and economic empowerment independently, where their effect is designed to be moderated by social capital consisting of bonding, bridging, and linking. Taking into account the potential of the UA program, improved community participation may lead to a high level of social capital and improve the empowerment of the community. This study explored the social capital and empowerment of UA program's respondents in the Klang Valley area. This study also specifically evaluated how the interaction between the independent variable (participation) and moderator variables (social capital) affected empowerment. For the direct relationship analysis, the results indicated a non-significant relationship between participation, social capital, and empowerment. For the interaction analysis, participation moderated by social capital resulting insignificant relationship. In other words, the moderation analysis portrayed that social capital among UA program's respondents is still moderate and unable to regulate the relationship between participation and empowerment.

\section{References}

Abbott, S. (2010). Social capital and health: The role of participation. Social Theory \& Health, 8(1), 51-65.

Abdul-Hakim, R., Abdul-Razak, N. A., \& Ismail, R. (2010). Does social capital reduce poverty? A case study of rural households in Terengganu, Malaysia. European Journal of Social Sciences, 14(4), 556-566.

Abdul Hamid. (2008). Islamic Microfinance: A Catalyst Towards Muslim Women Empowerment In Nigeria. Social Science Education Journal, 3 (1).

Asomani-Boateng, R. (2002). Urban cultivation in Accra: an examination of the nature, practices, problems, potentials and urban planning implications. Habitat International, 26(4), 591-607.

Ani, F., Ramlan, N., Suhaimy, K. A. M., Jaes, L., Damin, Z. A., Halim, H., \& Ahmad, S. (2018). Applying empowerment approach in community development. Proceedings of the International Conference on Social Sciences, 1, 1. 
Babaei, H., Ahmad, N., \& Gill, S. S. (2012). Bonding, bridging and linking social capital and empowerment among squatter settlements in Tehran, Iran. World Applied Sciences Journal, 17(1), 119-126.

Bridger, J. C., \& Alter, T. R. (2006). Place, community development, and social capital. Community Development, 37(1), 5-18.

Brown, L. D. (2005). Making it sane: The participation benefits of consumer-run organizations. [Doctoral thesis, Wichita State University]. https://www.proquest.com/docview/305384983?pqorigsite=gscholar\&fromopenview=true

Burton, I., \& Lim, B. (2005). Achieving adequate adaptation in agriculture. Climatic change, 70(1), 191-200.

Carolan, M. (2016). The sociology of food and agriculture. Routledge Press. https://doi.org/10.4324/9781315670935

Chambers, R., \& Conway, G. R. (1992). Sustainable rural livelihoods: Practical concepts for the 21st century (Working Paper No. 296). Institute for Development Studies.

Cofré-Bravo, G., Klerkx, L., \& Engler, A. (2019). Combinations of bonding, bridging, and linking social capital for farm innovation: How farmers configure different support networks. Journal of Rural Studies, 69, 53-64.

Cohen, N., \& Reynolds, K. (2014). Urban agriculture policy making in New York's "New Political Spaces" strategizing for a participatory and representative system. Journal of Planning Education and Research, 34(2), 221-234.

Craig, G., \& Mayo, M. (1995). Community empowerment: A reader in participation and development. Sociology Mind, 5(3), 38-50.

Danjuma, S. K., Malami, H. U., \& Gatawa, N. M. (2011). Skill acquisition, capacity building and women economic empowerment: A case study of Women Education Center, Birnin Kebbi. Gender and Behaviour, 9(2), 3961-3978.

Davies, J., Hannah, C., Guido, Z., Zimmer, A., McCann, L., Battersby, J., \& Evans, T. (2021). Barriers to urban agriculture in Sub-Saharan Africa. Food Policy, 103, 101999.

Department of Agriculture (2018). Program Pertanian Bandar 2018. http://www.doa.gov.my/index.php/pages/view/332

Ding, D., Liu, P., \& Ravenscroft, N. (2018). The new urban agricultural geography of Shanghai. Geoforum, 90, 74-83.

Duchemin, E., Wegmuller, F., \& Legault, A. M. (2008). Urban agriculture: multi-dimensional tools for social development in poor neighbourhoods. The Journal of Field Actions, 1, 200-217.

Egli, V., Oliver, M., \& Tautolo, E. S. (2016). The development of a model of community garden benefits to wellbeing. Preventive Medicine Reports, 3, 348-352.

Eklinder-Frick, J., Eriksson, L. T., \& Hallén, L. (2012). Effects of social capital on processes in a regional strategic network. Industrial Marketing Management, 41(5), 800-806.

Farrington, J., Carney, D., Ashley, C., \& Turton, C. 1999. Sustainable livelihoods in practice: Early applications of concepts in rural areas. (Working Paper No. 42).

Getz, C. (2008). Social capital, organic agriculture, and sustainable livelihood security: Rethinking agrarian change in Mexico. Rural Sociology, 73(4), 555-579.

Gong, Y., Bull, G., \& Baylis, K. (2010). Participation in the world's first clean development mechanism forest project: the role of property rights, social capital and contractual rules. Ecological Economics, 69(6), 1292-1302. 
Hair, J. F., Hult, G. T. M., Ringle, C. M., \& Sarstedt, M. (2014) A Primer on Partial Least Squares Structural Equation Modeling (PLS-SEM). Sage Publication.

Hair, J. F., Celsi, M., Ortinau, D. J., \& Bush, R. P. (2010). Essentials of marketing research. McGraw-Hill Press.

Hair, J. F., Ringle, C. M., \& Sarstedt, M. (2011). PLS-SEM: Indeed a silver bullet. Journal of Marketing Theory and Practice, 19 (2), 139-152.

Haldane, V., Chuah, F. L., Srivastava, A., Singh, S. R., Koh, G. C., Seng, C. K., \& Legido-Quigley, H. (2019). Community participation in health services development, implementation, and evaluation: A systematic review of empowerment, health, community, and process outcomes. PloS One, 14(5), e0216112.

Hara, Y., Yoshii, T., Tsujimura, K., Sampei, Y. (2016) Land use and land ownership characteristics of designated disaster evacuation farmland in Sakai city, Japan. Center Research Education Disaster.

Heenan, D. (2010). Social capital and older people in farming communities. Journal of Aging Studies, 24(1), 40-46.

Henseler, J., \& Fassott, G. (2010). Testing moderating effects in PLS path models: An illustration of available procedures. Springer.

Hovorka, A. J. (2006). The (re) production of gendered positionality in Botswana's commercial urban agriculture sector. Annals of the Association of American Geographers, 95(2), 294-313.

Ibrahim, M. B. (2016). Role of participation in decision making and social capital on sustainability of watershed usage among peri-urban agricultural farmers of Kwadon, Gombe State, Nigeria. [Doctoral dissertation, Universiti Putra Malaysia].

Kim, S. H. (2007). Media use, social capital, and civic participation in South Korea. Journalism \& Mass Communication Quarterly, 84(3), 477-494.

Kumar, A. (2006). Self-help Groups, Women's Health and Empowerment: Global Thinking and Contextual Issues. Women's Health and Empowerment: Global Thinking and Contextual Issues (January 21, 2009). Journal of Development and Management Studies, 4(3), 20612079.

Kutiwa, S., Boon, E., \& Devuyst, D. (2010). Urban agriculture in low income households of Harare: an adaptive response to economic crisis. Journal of Human Ecology, 32(2), 8596.

Lim, J. H. (2010). Empowering Citizens'voices In The Era Of E-Government: Implications From South Korean Cases. Theoretical and Empirical Researches in Urban Management, 5(7 (16), 19-31.

Lyndon, N., Razak, N., Azima, A. M., Junaidi, A. B., \& Sivapalan, S. (2015). Empowerment of the bidayuh rural community oil palm smallholders: A case study in serian district, sarawak, Malaysia. Mediterranean Journal of Social Sciences, 6(4), 55-55.

Mackay, H. (2018). Mapping and characterising the urban agricultural landscape of two intermediate-sized Ghanaian cities. Land use policy, 70, 182-197.

Martin-Prevel, Y., \& Traissac, P. (2012). Alternatives to principal components analysis to derive asset-based indices to measure socio-economic position in low-and middleincome countries: the case for multiple correspondence analysis. International journal of epidemiology, 41(4), 1207-1208.

Marks, S. J., \& Davis, J. (2012). Does user participation lead to sense of ownership for rural water systems? Evidence from Kenya. World Development, 40(8), 1569-1576. 
McDougall, R., Kristiansen, P., \& Rader, R. (2019). Small-scale urban agriculture results in high yields but requires judicious management of inputs to achieve sustainability. Proceedings of the National Academy of Sciences, 116(1), 129-134.

Narayan, D., \& Pritchett, L. (2000). Social capital: Evidence and implications. Social capital: A multifaceted perspective, 269-295.

Ndaeji, M. N. (2014). Participation in Self-help Groups and Empowerment among Rural Women in Niger State, Nigeria [Doctoral dissertation, Universiti Putra Malaysia]

Nemore, C. (1998). Rooted in community: community gardens in New York City. City Farmer. http://www.cityfarmer.org/NYcomgardens.html

Nikkhah, H. A., \& Ma'rof R. (2009). Participation as a Medium of Empowerment in Community Development. European Journal of Social Sciences, 11(1) 170-176.

Oakley, P. (1989). Community Involvement in Health Development: An Examination of the Critical Issue. World Health Organization.

Orsini, F., Kahane, R., Nono-Womdim, R., \& Gianquinto, G. (2013). Urban agriculture in the developing world: a review. Agronomy for Sustainable Development, 33(4), 695-720.

Othman, N., Latip, R. A., Ariffin, M. H., \& Mohamed, N. (2017). Expectancy in urban farming engagement. Environment-Behaviour Proceedings Journal, 2(6), 335-340.

Othman, N., Latip, R. A., \& Ariffin, M. H. (2019). Motivations for sustaining urban farming participation. International Journal of Agricultural Resources, Governance and Ecology, 15(1), 45-56.

Othman, N., Mohammad, S. Z., Abd Malek, N., \& Razak, M. A. W. A. (2020). Deterrent Factors in Urban Farming Participation. Environment-Behaviour Proceedings Journal, 5(13), 353-358.

Park, D. B., Nunkoo, R., \& Yoon, Y. S. (2015). Rural residents' attitudes to tourism and the moderating effects of social capital. Tourism Geographies, 17(1), 112-133.

Poulsen, M. N., McNab, P. R., Clayton, M. L., \& Neff, R. A. (2015). A systematic review of urban agriculture and food security impacts in low-income countries. Food Policy, 55, 131-146.

Rahman, M. A., \& Naoroze, K. (2007). Women empowerment through participation in aquaculture: Experience of a large-scale technology demonstration project in Bangladesh. Journal of Social Sciences, 3(4), 164-171.

Rakodi, C. (2002). A people-centred approach to reducing poverty. Earthscan.

Rappaport, J. (1987). Terms of empowerment/exemplars of prevention: Toward a theory for community psychology. American Journal of Community Psychology, 15(2), 121-148.

Ramalingam, L., Sharifuddin, J., Ali, F., \& Mohamed, Z. (2018). Community Garden Programme: An Analysis of Volunteers' Motivations and Age Groups. Journal of Humanities and Social Sciences, 23, 48-53.

Ramalingam, L., Sharifuddin, J., Mohamed, Z. A., \& Ali, F. (2019). Motivation and satisfaction of volunteers for community-based urban agriculture programmes. International Social Science Journal, 69(231), 49-62.

Ramaloo, P., Liong, C. Y., Siwar, C., \& Isahak, A. (2018). Perception of Community Residents on Supporting Urban Agriculture in Malaysian City: Case Study at Bukit Mertajam. Jurnal Pengurusan, 53, 100-115

Rezai, G., Shamsudin, M. N., \& Kit Teng, P. (2014). Public attitude toward urban agriculture in Malaysia: study on values and knowledge in Klang Valley. Journal of Food Products Marketing, 20, 35-48.

Rezai, G., Shamsudin, M. N., \& Mohamed, Z. (2016). Urban agriculture: a way forward to food and nutrition security in Malaysia. Procedia-Social and Behavioral Sciences, 216, 39-45. 
Rilwanu, A. (2014). Participation, Social Capital and Empowerment among Members of Kankara Local Community Fadama User Groups in Katsina State, Nigeria [Doctoral dissertation, Universiti Putra Malaysia].

Rondhi, M., Pratiwi, P. A., Handini, V. T., Sunartomo, A. F., \& Budiman, S. A. (2018). Agricultural land conversion, land economic value, and sustainable agriculture: A case study in East Java, Indonesia. Land, 7(4), 148.

Rust, N. A., Ptak, E., Graversgaard, M., Iversen, S., Reed, M. S., de Vries, J., \& Dalgaard, T. (2020). Social capital factors affecting uptake of sustainable soil management practices: a literature review. Emerald Open Research, 2(8).

Samah, A. A., \& Aref, F. (2009). People's participation in community development: A case study in a planned village settlement in Malaysia. World Rural Observations, 1(2), 4554.

Samah, A. A., \& Ndaeji, M. N. (2012). Women participation in Self-Help development projects as an instrument for rural women empowerment in Nigeria. The Journal of American Science, 8(4), 763-771.

Shamsudin, M. N., Rezai, G., \& Kit Teng, P. (2014). Public attitude toward urban agriculture in Malaysia: study on values and knowledge in Klang Valley. Journal of Food Products Marketing, 20(sup1), 35-48.

Sheikh, M. J., Redzuan, M. R., Samah, A. A., \& Ahmad, N. (2015). Identifying sources of social capital among the farmers of the rural Sindh province of Pakistan. Agricultural Economics, 61(4), 189-195.

Shimpo, N., Wesener, A., \& McWilliam, W. (2019). How community gardens may contribute to community resilience following an earthquake. Urban Forestry \& Urban Greening, 38, 124-132.

Shirlow, P., \& Murtagh, B. (2004) Capacity-building, representation and intracommunity conflict, Urban Studies, 41, 57-71.

Smith, S. S. (2005). "Don't put my name on it": Social capital activation and job- finding assistance among the black urban poor. American Journal of Sociology, 111(1), 1-57.

Specht, K., Siebert, R., Hartmann, I., Freisinger, U. B., Sawicka, M., Werner, A., \& Dierich, A. (2014). Urban agriculture of the future: an overview of sustainability aspects of food production in and on buildings. Agriculture and Human Values, 31(1), 33-51.

Stewart, R., Korth, M., Langer, L., Rafferty, S., Da Silva, N. R., \& van Rooyen, C. (2013). What are the impacts of urban agriculture programs on food security in low and middleincome countries? Environmental Evidence, 2(1), 1-13.

Straub, D., Boudreau, M. C., \& Gefen, D. (2004). Validation guidelines for IS positivist research. Communications of the Association for Information systems, 13(1), 24.

Strzelecka, M., Boley, B. B., \& Woosnam, K. M. (2017). Place attachment and empowerment: Do residents need to be attached to be empowered? Annals of Tourism Research, 66, 61-73.

Tajuddin, Z., Sum, S. M., Zainol, R. M., \& Jusoh, H. (2019). Penentu Sosial Penglibatan Komuniti dalam Projek Kebun Komuniti Bandar. SARJANA, 34(1), 56- 68.

Turner, B. (2011). Embodied connections: sustainability, food systems and community gardens. Local Environment, 16(6), 509-522.

Viscogliosi, C., Asselin, H., Basile, S., Borwick, K., Couturier, Y., Drolet, M. J., \& Levasseur, M. (2020). Importance of Indigenous elders' contributions to individual and community wellness: results from a scoping review on social participation and intergenerational solidarity. Canadian Journal of Public Health, 111(5), 667-681. 
Wilson, P. A. (1996). Empowerment: Community economic development from the inside out. Urban Studies, 33(4-5), 617-630.

Yokoyama, S., \& Ishida, A. (2006). Social capital and community development: A review. Potential of social capital for community development.

Yusoff, N. H., Hussain, M. R. M., \& Tukiman, I. (2017). Roles of community towards urban farming activities. Planning Malaysia, 15(1).

Zal, W. A., Ma'Rof Redzuan, A. A. S., \& Hamsan, H. H. (2013). The exploration of social capital and its relation with economic empowerment of Orang Kuala in Johor, Malaysia. Pertanika Journal Social Sciences and Humanities, 21(4), 1275-1295

Zimmerman, M. A., \& Rappaport, J. (1988). Citizen participation, perceived control, and psychological empowerment. American Journal of Community Psychology, 16(5), 725-750. 